\title{
Effect of natural and artificial drying of leaf biomassof Psidium guajava on the content and chemical composition of essential oil
}

\section{Efeito da secagem natural e artificial da biomassa foliar de psidium guajava sobre o teor e a composição química do óleo essencial}

\author{
Elizabeth Aparecida Josefi da Silva ${ }^{1 *}$; Vanessa Paula da Silva ${ }^{2}$; \\ Cassia Cristina Fernandes Alves ${ }^{3}$; José Milton Alves ${ }^{4}$; \\ Edson Luiz Souchie ${ }^{5}$, Luiz Cláudio Almeida Barbosa ${ }^{6}$
}

\begin{abstract}
Psidium guajava L. is native to Central and South America. It is widely distributed and well adapted to Brazil, a producer of essential oils rich in terpenes. The objective of this study was to evaluate the effects of natural and artificial drying on the content and chemical composition of the essential oil of guava leaves (Psidium guajava L.) grown in Rio Verde (GO). The two treatments consisted of drying fresh leaves either naturally in the shade or artificially at $40^{\circ} \mathrm{C}$. Chemical composition was analyzed qualitatively and quantitatively by gas coupled with mass spectrometer chromatography (GC/MS) and gas chromatography using a flame ionizer (GC-FID), respectively. The method of drying changed the content and chemical composition of the essential oil of guava leaves. Drying in the shade reduced the content and altered the constituents of the essential oil, whereas drying in an oven at $40^{\circ} \mathrm{C}$, despite having reduced the amounts of the constituents, exhibited the highest essential oil content and increased the concentration of certain major constituents as compared to that in the natural shade drying method. The major components found in the essential oil of leaves regardless of the drying processes were transcaryophyllene, $\alpha$-humulene, aromadendrene, $\alpha$-selinene, and selin-11-en- $4 \alpha$-ol. According to reports in the literature, these compounds possess fungicidal, insecticidal, antimicrobial, and anti-inflammatory activity, among others beneficial actions.
\end{abstract}

Key words: Hydrodistillation. Guava. Myrtaceae. Medicinal plants.

\section{Resumo}

Psidium guajava L. é uma planta nativa da América Central e do Sul, que está amplamente distribuída e bem adaptada no território brasileiro, produtora de óleo essencial rico em terpenos. O objetivo deste estudo foi avaliar o efeito da secagem natural e artificial sobre o teor e a composição química do óleo essencial das folhas de goiabeira (Psidium guajava L.), cultivada em Rio Verde (GO). Os tratamentos avaliados foram: folhas frescas; secagem natural à sombra e secagem em estufa a $40^{\circ} \mathrm{C}$. A composição química qualitativa e quantitativa foi analisada por cromatografia gasosa acoplada ao espectrômetro de

1 Discente de Doutorado em Ciências Agrárias, Instituto Federal Goiano Campus Rio Verde, IFG/RV, Rio Verde, GO, Brasil. E-mail: elizabethjosefi@yahoo.com.br

2 Discente de Mestrado em Agroquímica, IFG/RV, Rio Verde, GO, Brasil. E-mail: vanessapaula221993@gmail.com

3 Prof ${ }^{\mathrm{a}} \mathrm{Dr}^{\mathrm{a}}$, em Química, IFG/RV, Rio Verde, GO, Brasil. E-mail: cassiacefetrv@gmail.com

4 Prof. Dr., em Agronomia/Ciências do Solo, Instituto Federal Goiano Campus Rio Verde, IFG/RV, Rio Verde, GO, Brasil. E-mail: jmiltonalves@gmail.com

5 Prof. Dr., em Agronomia/Solo e Água, IFG/RV, Rio Verde, GO, Brasil. E-mail: edson.souchie@ifgoiano.edu.br

6 Prof. Dr. Universidade Estadual de Viçosa, UFV, Viçosa, MG, Brasil. E-mail: lcab@outlook.com

Author for correspondence 
massa (CG/MS) e cromatógrafo gasoso com ionizador de chama (CG-FID), respectivamente. O tipo de secagem alterou o teor e a constituição química do óleo essencial das folhas de goiabeira. A secagem a sombra reduziu o teor e a quantidade de constituintes do óleo essencial, enquanto a secagem em estufa a $40^{\circ} \mathrm{C}$ apesar de ter reduzido a quantidade de constituintes, apresentou o maior teor de óleo essencial e aumentou a concentração de alguns constituintes majoritários em relação à secagem natural a sombra. Os componentes majoritários encontrados tanto no óleo essencial das folhas in natura quanto no óleo essencial obtido das folhas submetidas aos processos de secagem foram trans-cariofileno, $\alpha$-humuleno, aromadendreno, $\alpha$-selineno e o selin- 11 -en- $4 \alpha$-ol, e segundo relatos na literatura estes compostos possuem atividades fungicidas, inseticidas, antimicrobianas, anti-inflamatórias, entre outras.

Palavras-chave: Hidrodestilação. Goiabeira. Myrtaceae. Plantas medicinais.

\section{Introduction}

Psidium guajava (L.), commonly known as "guava," is a shrub or small fruit tree, belonging to the family Myrtaceae, genus Psidium, and is native to Central and South America. It is cultivated in all countries with tropical or subtropical climates, and is well adapted to and widely distributed in the Brazilian territory (GUTIÉRREZ et al., 2008; SHAH et al., 2011; TAVARES et al., 2002). In popular medicine, it is used to treat colic, colitis, diarrhea, dysentery, and stomach pain (KANERIA; CHANDA, 2011). Published data show that the extracts of leaves of this species present several pharmacological properties, such as antimicrobial, antispasmodic, hypoglycemic, anti-diabetic, antioxidant, antimutagenic, and anti-carcinogenic activity (BAKKALI et al., 2008; GUTIÉRREZ et al., 2008; SOMAN et al., 2013).

The leaves contain an essential oil that is rich in important insecticidal and pharmacologically active compounds, such as $\alpha$-pinene, limonene, 1,8-cineole, trans-caryophyllene, and $\alpha$-humulene (LIMA et al., 2009). Essential oils are natural products obtained from different parts of medicinal and aromatic plants through hydrodistillation (ISO, 1997), being designated as oil because of some of their physiochemical characteristics, such as being volatile, lipophilic, usually odorous, and liquid at room temperature (SIMÕES et al., 2007). These compounds are important in the preparation of products in the pharmaceutical, food, and cosmetic industries, as well as in agriculture for the biological control of pests and diseases (SOUZA et al., 2010; TELES, 2010).
Several factors can cause alterations in the content of essential oils and their therapeutic and flavoring properties, including as soil characteristics, climate, and even the post-harvest processing of the plant material. In terms of post-harvest processing, the factor that most greatly affects the content and chemical composition of the essential oil is drying. Drying consists of the withdrawal of free water present in plant tissues, preventing enzymatic degradation from occurring, and thus maintaining the quality of the plant materials (ISENBERG; NOZAKI, 2011; ROSADO et al., 2011). The leaves of medicinal and aromatic plants are often dried before the extraction of essential oils to reduce their moisture content; however, during this process many of the more volatile compounds are lost because they are removed during water evaporation. Thus, the drying method has a significant effect on the quality and quantity of essential oils of such plants (ASEKUN et al., 2007).

Studies have shown that the method of drying can affect the content and chemical composition of the essential oil (ANTAL et al., 2011; SHAHHOSEINI et al., 2013). For example, some medicinal and aromatic plants exhibited a reduction in the content of essential oil when subjected to natural drying at ambient temperature: $45-36 \%$ for basil (Ocimum basilicum), 33-23\% for marjoram (Origanum majorana), and 17-6\% for oregano (Origanum vulgare) (SHAHHOSEINI et al., 2013). Khangholi and Rezaeinodehi (2008) verified that the content of essential oil of Artemisia annua decreased after drying in an oven at higher temperatures. Sellami et al. (2011), when studying the influence of different 
drying methods on Laurus nobilis, found that natural drying at ambient temperature and infrared drying at $45^{\circ} \mathrm{C}$ significantly increased the content of essential oil of the studied species.

Asekun et al. (2007) studied the effect of sun drying, shade drying at ambient temperature, and drying in an oven at $40^{\circ} \mathrm{C}$ on the quantity and chemical quality of the essential oil of wildmint leaves (Mentha longifolia). They concluded that the monoterpenoids in the essential oil underwent a significant chemical transformation because of the drying process. When assessing the influence of drying temperature on content and chemical composition of the essential oil of Guaco (Mikania glomerata Spreng.), Radünz et al. (2010) also concluded that there was a change in the chromatographic identification of the essential oil caused by the drying process in comparison with the plant in natura. However, research related on the drying process is still insufficient and there is an increasing need for specific studies on medicinal species, because their behavior under various drying processes is unique. For this reason, the definition of more appropriate drying methods for each species is essential to ensure the amount of essential oil as well as the active substances (BORSATO, 2006; CORRÊA et al., 2004; KHATER et al., 2011; MACHADO et al., 2013).

Therefore, the choice of the best drying method and essential oil extraction technique is necessary to increase the efficiency and reduce loss of active substances. Thus, the objective of the present study was to identify the effect of different drying methods on the quantity and quality of the essential oil of Psidium guajava leaves.

\section{Materials and Methods}

\section{Plant material}

The experiment was conducted at the Natural Products Chemistry Laboratory at the Goiás Institute of Education, Science and Technology, IF
Goiano Campus Rio Verde, using fresh leaves of Psidium guajava. The leaves were collected in the city of Rio Verde, GO, at $17^{\circ} 48^{\prime} 28^{\prime \prime} \mathrm{S}, 50^{\circ} 53^{\prime} 57^{\prime \prime}$ $\mathrm{W}$ at an altitude of $720 \mathrm{~m}$, between $0600 \mathrm{~h}$ and 0800 $\mathrm{h}$ in July 2014. The plant material was identified, and samples were deposited as voucher specimens in the Herbarium of the State University of Montes Claros MG, under the identification number 4481.

The leaves were collected from the top and bottom of the plant, packed in plastic bags, and brought to the Natural Products Chemistry Laboratory of the IF Goiano, Rio Verde Campus. After collection, the leaves underwent a screening process, and leaves in poor condition were discarded.

\section{Determination of moisture content}

The moisture content of the leaves was determined before and after drying, in accordance with the methodology for forage and similar materials plants and leaves (ASAE, 2000). To determine the moisture content, the leaves were placed in an oven with forced air at a temperature of $103 \pm 2^{\circ} \mathrm{C}$ for $24 \mathrm{~h}$. Three identical samples were evaluated. The initial moisture content of leaves was $63.69 \%$ wet-basis (\% wb). During the drying process, the samples were weighed periodically until a moisture content of approximately $10.02 \%$ was achieved.

\section{Drying}

Drying was performed using two treatments: drying in an oven at $40^{\circ} \mathrm{C}$ with forced air circulation and shade drying at ambient temperature (27.0 \pm $4^{\circ} \mathrm{C}$ ) and $61 \%$ average relative air humidity. In both treatments, leaves were dried to a constant weight using six replicates of $100 \mathrm{~g}$. The leaves were placed in Kraft paper bags for oven drying and on Kraft paper bags for shade drying at ambient temperature. The reduction in the water weight during the drying process was monitored by the gravimetric method (weight loss), based on the initial water content of 
the product, until constant weight and desired water content was attained. Monitoring of mass reduction during drying was performed using an analytical balance with resolution of $0.0001 \mathrm{~g}$. The air temperature was monitored using a mercury-column thermometer with a range of $-10^{\circ} \mathrm{C}$ to $300^{\circ} \mathrm{C}$ for oven drying and a digital thermo hygrometer with a precision of $3 \%$ for drying at room temperature.

\section{Essential oil extraction}

Extraction of essential oil was performed by hydrodistillation in a Clevenger apparatus with a 1-L volumetric flask; hydrodistillation continued for $2 \mathrm{~h}$ from the start of boiling. The extractions were performed from $100 \mathrm{~g}$ samples with six replicates of the following treatments: fresh leaves (extraction performed immediately after collection of plant material); leaves dried in the shade at ambient temperature; and dried leaves at $40^{\circ} \mathrm{C}$ in an oven. The essential oil was extracted from the aqueous phase using dichloromethane $(3 \times 10 \mathrm{~mL} ; 20 \mathrm{~min}$ each extraction), and dehydrated with anhydrous sodium sulfate. After $30 \mathrm{~min}$, the sulfate was removed by filtration. After complete evaporation of the solvent, the mass content of the essential oil was determined using an analytical balance with a resolution of $0.0001 \mathrm{~g}$. The samples were stored at $4^{\circ} \mathrm{C}$ in a refrigerator for later analysis of chemical composition.

\section{Quantification and identification of chemical composition}

Quantification of the compounds in the essential oils was performed using a Shimadzu GC-17 $7^{\text {a }}$ gas chromatograph equipped with a flame ionization detector (FID) and SPB-5 fused silica capillary column $(30 \mathrm{~m} \times 0.25 \mathrm{~mm}$, film thickness 0.25 $\mu \mathrm{m})$. Chromatography was performed under the following conditions: carrier gas $\left(\mathrm{N}_{2}\right)$ flow rate $1.8 \mathrm{~mL} \mathrm{~min}^{-1}$; temperature of the injector $220^{\circ} \mathrm{C}$, detector temperature $240^{\circ} \mathrm{C}$; and initial column temperature $40^{\circ} \mathrm{C}$. Conditions were isothermal for 4 min, followed by heating at $3^{\circ} \mathrm{C} \min ^{-1}$ to $240^{\circ} \mathrm{C}$, and remaining isothermal for $15 \mathrm{~min}$. Sample injection volume was $1.0 \mu \mathrm{L}\left(10 \mathrm{mg} \mathrm{mL}^{-1}\right.$ in $\left.\mathrm{CH}_{2} \mathrm{Cl}_{2}\right)$, split ratio was $1: 10$, and column pressure was $115 \mathrm{kPa}$.

The identification of the essential oil compounds was performed with a Shimadzu GC-17 $7^{\text {a }}$ gas chromatograph equipped with a RTX-5 fused silica column (30 $\mathrm{m} \times 0.25 \mathrm{~mm}$, film thickness $0.25 \mu \mathrm{m})$ coupled to a Shimadzu CGMS-QP5050A mass spectrometer. The chromatographic conditions were the same as used for the CG-FID, except the carrier gas was $\mathrm{He}$ and the column pressure was $100 \mathrm{kPa}$. With regard to the mass spectrometer, the ionization process was by electron impact $(70 \mathrm{eV})$ and scan amplitude was 30 to $700 \mathrm{Da}$.

The quantification of the compounds was performed in triplicate and the concentration of each constituent was calculated as the percentage of the area of the corresponding peak relative to the total area of all peaks observed in the chromatogram. The identification of the compounds was made via comparison of their mass spectra and retention indices (RI) with those of the standard substances in system libraries (Wiley 7th edition) and in the literature (ADAMS, 2007). The RIs were obtained using a homologous series of n-alkanes. The identification of the constituents of the essential oil was performed at the Laboratory of Analysis and Synthesis of Agrochemicals, Federal University of Viçosa (UFV).

\section{Statistical analysis}

The experimental design was a completely randomized design with six replicates. An analysis of variance (ANOVA) was conducted with the data and the averages of the treatments were compared by Tukey's test at the $5 \%$ level of significance using ASSISTAT software. 


\section{Results and Discussion}

The time to obtain constant weight of guava leaves is shown in Figure 1. The loss of water by plant tissues was more rapid during the first hours of drying and tended to stabilize by the fourth day. For oven drying, a constant weight was obtained after 8 days of drying, whereas for shade drying at ambient temperature, constant weight was obtained at 16 days, at which time both drying processes were terminated. The moisture observed in the leaves at the end of the drying period was below $13 \%$ for both methods, which is in accordance with the recommendations of various pharmacopoeias (i.e., between 8 and 14\% w.b.) (FARIAS et al., 2004).

Figure 1. Drying curve of Psidium guajava L. leaves subjected to natural shade drying and artificial drying in an oven at $40^{\circ} \mathrm{C}$.

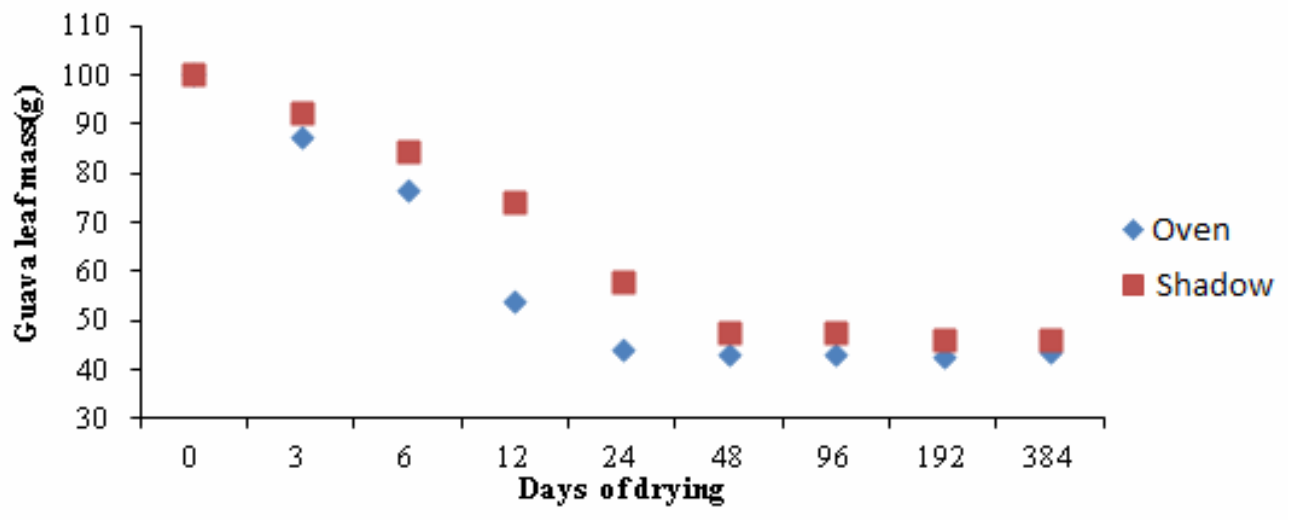

Oil content was modified by the drying method. The highest yield was obtained by artificial drying in an oven at $40^{\circ} \mathrm{C}$, being $0.34 \%$ dry basis (d.b.). The yield of essential oil of the fresh leaves $(0.27 \%$ d.b.) was lower than that of leaves dried artificially or by natural shade drying $(0.30 \%$ d.b). According to Martins et al. (2002), the lower water content in the leaves dried in an oven at $40^{\circ} \mathrm{C}$ allows the vapor stream generated during the hydrodistillation to more efficiently carry the volatile substances stored in the cells of the plant material when compared with the material in natura. According to Guenther (1972), because the plant material in natura has high water content, there is a strong agglutination of the essential oil, preventing the steam from penetrating plant tissues uniformly and efficiently. Similar results were found by Rosas et al. (2004) when studying the effect of different drying methods on the content of essential oil of the basil leaves, noting that drying in an oven at $35^{\circ} \mathrm{C}$ produced more essential oil in this species in comparison with drying with a dehumidifier.
Corrêa et al. (2004) studied the effect of various drying methods (oven at $35^{\circ} \mathrm{C}$, solar drier at $32^{\circ} \mathrm{C}$, mixed drying at $27^{\circ} \mathrm{C}$, and shade drying at $25^{\circ} \mathrm{C}$ ), and found less essential oil of Vernonia polyanthes Less. was produced following drying in the oven. Rosado et al. (2011) studied the influence of leaf processing and the type of drying on the essential oil content of basil and observed that oven drying resulted in more essential oil compared to plant material subjected to drying in a dehumidifier. In addition, Omidbaigi et al. (2004) studied the influence of the drying method on the content of essential oil of chamomile (Chamaemelum nobile). They compared natural shade drying, sun drying, and oven drying at $40^{\circ} \mathrm{C}$ and observed that the natural shade drying led to a higher yield of essential oil than the other methods evaluated, thus showing that for each species there is a specific drying method that will generate the highest content of essential oil from the plant material. 
In the majority of the studies conducted on the drying of medicinal plants, the authors concluded that the drying temperature influenced the yield of essential oil, i.e., for each species there is a specific drying method that will yield the greatest amount of essential oil from the plant material.

Thirteen to 17 compounds were identified in the essential oil of P. guajava, depending on the drying method used, which corresponded to $91.44 \%$ of the total oil analyzed (Table 1 ). The method of biomass drying changed the chemical composition of the essential oil of guava leaves; 17 compounds were identified in the essential oil extracted from fresh leaves, whereas 13 and 15 compounds were identified in the oil from naturally and artificially dried leaves, respectively. The major constituents were trans-caryophyllene, $\alpha$-humulene, aromadendrene, $\alpha$-selinene, and selin11 -en- $4 \alpha$-ol. They occurred at different proportions depending upon the drying method. In fresh leaves the proportions were trans-caryophyllene, $18.18 \%$; $\alpha$-humulene, 26.37\%; aromadendrene, $7.63 \%$; $\alpha$-selinene, 7.35\%; and selin-11-en- $4 \alpha$-ol, 7.20\%. In shade-dried leaves they were trans-caryophyllene, 9.04\%; $\alpha$-humulene, $10.21 \%$; aromadendrene, $8.39 \% ; \alpha$-selinene, $7.30 \%$; and selin-11-en- $4 \alpha-$ ol, $12.52 \%$. In oven-dried leaves they were transcaryophyllene, $13.86 \%$; $\alpha$-humulene, $15.61 \%$; aromadendrene, $11.16 \%$; $\alpha$-selinene, $10.32 \%$; and selin-11-en- $4 \alpha$-ol, $11.20 \%$.

Thus, the process of natural and artificial drying of guava leaves increased the content of essential oil compared with the oil content of leaves in natura. However, there was a reduction in the concentrations of the major compounds trans-caryophyllene and $\alpha$-humulene, and an increase in the concentrations of aromadendrene, $\alpha$-selinene, and selin-11-en- $4 \alpha$ ol with drying methods in comparison to that of the plant material in natura. Thus, artificial drying in an oven resulted the highest content of essential oil compared to the other treatments, but also decreased the concentration of trans-caryophyllene and $\alpha$-humulene.
The special metabolites identified in the essential oil of the species studied are similar to previously published metabolites present in the essential oil extracted from the guava leaves. Craveiro et al. (1981), Cuellar et al. (1984), and Pino et al. (2001) characterized the essential oil of guava leaves and identified 21 compounds, including $\alpha$ - humulene, trans-caryophyllene, and selin-11-en-4 $\alpha$-ol.

The major compounds identified as components of the essential oil of the guava leaves both in natura and those submitted to drying methods have biological activity supported by published data. Mevy et al. (2007) studied the essential oil of Lippia chevalieri, whose major constituent is trans-caryophyllene, and observed antibacterial and antifungal activity. Lippia chevalieri is traditionally used in the treatment of respiratory diseases of bacterial and fungal origins. In addition, Castro (2004) evaluated the insecticidal activity of the essential oil of yarrow (Achillea millefolium $L$. ), and one of the major compounds was transcaryophyllene, at a concentration of $3.52 \%$.

According to Deus et al. (2011), the fungicidal effect of the essential oil of copaiba can be related to the concentrations of $\alpha$-humulene and $\beta$-caryophyllene. Fernandes et al. (2007) concluded that $\alpha$-humulene derived from the essential oil of C. verbenacea might represent an important tool for the management and/or treatment of inflammatory diseases.

Similarly, Freitas et al. (2016) assessed the fungicidal potential of essential oil of Baccharis dracunculifolia and observed that it inhibited the growth of Fusarium species by $100 \%$. Its component compounds were nerolidol, spathulenol, $\delta$-cadinene, and aromadendrene (ranging from 5 to $25 \%$ in this species), among others, and these compounds may be related with the antifungal activity of this oil (FERRONATTO et al., 2007). 
Table 1. Average values of the levels (\%) of chemical constituents of the essential oil of guava (P. guajava) leaves for each drying method.

\begin{tabular}{lcccc}
\hline \multicolumn{1}{c}{ Compounds of essential oil } & \multirow{2}{*}{$\mathbf{R I}$} & \multicolumn{3}{c}{ Treatments } \\
\cline { 3 - 5 } & & $\mathbf{1}$ & $\mathbf{2}$ & $\mathbf{3}$ \\
\hline Limonene & 1024 & $2.22 \pm 0.2$ & $6.88 \pm 0.2$ & $4.75 \pm 0.2$ \\
1,8-cineol & 1026 & $1.50 \pm 0.3$ & - & $0.10 \pm 0.3$ \\
$\alpha$-copaene & 1374 & $1.05 \pm 0.3$ & $0.18 \pm 0.3$ & $0.28 \pm 0.3$ \\
trans- caryophyllene & 1419 & $18.18 \pm 0.4$ & $9.04 \pm 0.4$ & $13.86 \pm 0.4$ \\
$\alpha$-humulene & 1454 & $26.37 \pm 0.2$ & $10.21 \pm 0.2$ & $15.61 \pm 0.2$ \\
4,11-selinadiene & 1475 & $1.19 \pm 0.2$ & - & - \\
$\gamma$-muurolene & 1478 & $0.83 \pm 0.2$ & $0.77 \pm 0.2$ & $1.15 \pm 0.2$ \\
Aromadendrene & 1488 & $7.63 \pm 0.2$ & $8.39 \pm 0.2$ & $11.16 \pm 0.2$ \\
$\alpha$-selinene & 1497 & $7.35 \pm 0.3$ & $7.30 \pm 0.3$ & $10.32 \pm 0.3$ \\
$\alpha$-panasinsene & 1517 & $1.21 \pm 0.2$ & $0.22 \pm 0.2$ & $0.31 \pm 0.2$ \\
trans-nerolidol & 1566 & $3.38 \pm 0.2$ & - & $2.85 \pm 0.2$ \\
caryophyllene oxide & 1585 & $3.79 \pm 0.2$ & $5.95 \pm 0.2$ & $3.07 \pm 0.2$ \\
$\alpha$-humulene epoxide II & 1612 & $4.18 \pm 0.3$ & $4.75 \pm 0.3$ & $2.80 \pm 0.3$ \\
longipinene epoxide & 1620 & $1.61 \pm 0.2$ & $1.63 \pm 0.2$ & $1.23 \pm 0.2$ \\
epi- $\alpha$-muurulol & 1639 & $2.97 \pm 0.2$ & - & $3.52 \pm 0.2$ \\
$\alpha$-cadinol & 1651 & $0.78 \pm 0.3$ & $0.51 \pm 0.3$ & $1.33 \pm 0.3$ \\
selin-11-en-4 $\alpha$-ol & 1662 & $7.20 \pm 0.2$ & $12.52 \pm 0.2$ & $11.20 \pm 0.2$ \\
\hline & & 91.44 & 68.35 & 83.54 \\
\hline
\end{tabular}

1-Fresh leaves. 2-Natural drying. 3-Artificial drying in an oven at $40^{\circ} \mathrm{C}$. - not identified. Data represent mean \pm standard deviation. $\mathrm{RI}=$ retention index. Means \pm standard deviation.

Santos et al. (2014) also studied the fungicidal action of essential oil of Schinus terebinthifolius Raddi, and achieved $100 \%$ inhibition of the development of the phytopathogens studied. According to the authors, this fungicidal action might have occurred because of its chemical composition. A major compound of the essential oil of the leaves of this plant was $\alpha$-selinene (1.38\%). There are no published reports concerning any biological activity of the compound selin-11-en-4 $\alpha$-ol.

According to the results obtained, we conclude that drying methods altered the content and the chemical composition of the essential oil of guava leaves. Natural shade drying did not change the content of the essential oil when compared with the content of leaves in natura, whereas with oven drying the content of the essential oil was reduced. Oven drying reduced the relative amounts of major compounds in the essential oil and also their chemical variability; in contrast, it increased the levels of essential oil and also increased the concentration of some bioactive constituents, such as trans-caryophyllene, $\alpha$-humulene, aromadendrene, and $\alpha$-selinene, when compared with shade drying. In the present study, the essential oil presented major compounds with fungicidal, insecticidal, antibacterial, and anti-inflammatory characteristics, similar to those reported in the literature. Thus, artificial drying of guava leaves is the preferred drying method to increase of the concentration of these compounds, but the use of leaves in natura is also recommended when the cost benefit relationship is assessed. Even with reduced oil content, it offers oil with higher concentrations of bioactive compounds, such as trans-caryophyllene and $\alpha$-humulene. For this reason, the definition of appropriate drying methodologies for each species is necessary to ensure the appropriate levels of active substances, and the drying method should be defined according to the desired concentrations of active substances. 


\section{References}

ADAMS, R. P. Identification of essential oils components by gás chromatography/mass spectroscopy. New York: Allured Publishing, 2007. 804 p.

ANTAL, T.; FIGIEL, A.; KEREKES, B.; SIKOLYA, L. Effect of drying methods on the quality of the essential oil of spearmint leaves (Menthaspicata L.). Drying Technology, Philadelphia, v. 29, n. 15, p. 1836-1844, 2011.

ASAE STANDARDS. Standards Engineering Practices Data: Moisture Measurement - Forages, ASAE S358. 2 DEC99; Adopted and published by: American Society of Agricultural Engineers. St. Joseph: Asabe Standard, 2000. p. 565-572.

ASEKUN, O. T.; GRIERSON, D. S.; AFOLAYAN, A. J. Effects of drying methods on the quality and quantity of the essential oil of Mentha longifolia L. subsp. Capensis. Food Chemistry, London, v. 101, n. 3, p. 995-998, 2007.

BAKKALI, F.; AVERBECK, S.; AVERBECK, D.; IDAOMAR, M. Biological effects of essential oils - a review. Food and Chemical Toxicology, Kidlington, v. 46, n. 2, p. 446-475, 2008.

BORSATO, A. V. Rendimento e composição química do óleo essencial da camomila submetida à secagem em camada fixa. 2006. Tese (Doutorado em Ciências) - Departamento de Fitotecnia e Fitossanitarismo. Setor de Ciências Agrárias. Universidade Federal do Paraná, Curitiba.

CASTRO, H. G.; FERREIRA, F. A.; SILVA, D. J. H.; MOSQUIM, P. R. Contribuição ao estudo das plantas medicinais metabólitos secundários. 2. ed. Visconde do Rio Branco: Suprema, 2004. 99 p.

CORRÊA, R. M.; BERTOLUCCI, S. K. V.; PINTO, J. E. B. P.; REIS, É. S.; ALVES, T. L. Rendimento de óleo essencial e caracterização organoléptica de folhas de assa-peixe submetidas a diferentes métodos de secagem. Ciência e Agrotecnologia, Lavras, v. 28, n. 2, p. 339-344, 2004.

CRAVEIRO, A. A.; FERNANDES, A. G.; ANDRADE, C. H. S.; MATOS, F. J. A.; ALENCAR, J. W.; MACHADO, M. I. L. Óleos essenciais de plantas do Nordeste. [S.1.]: UFC, $1981.210 \mathrm{p}$.

CUELLAR, A. C.; LARA, R. A.; ZAYAS, J. P. Psidium guajava L. Tamizaje fitoquímico y estudio del aceite esencial. Revista Cubana de Farmácia, Ciudad de La Habana, v. 18, n. 1, p. 92-99, 1984.

DEUS, R. J. A.; ALVES, C. N.; ARRUDA, M. S. P. Avaliação do efeito antifúngico do óleo resina e do óleo essencial de copaíba (Copaifera multijuga Hayne).
Revista Brasileira de Plantas Medicinais, Botucatu, v. 13, n. 1, p. 1-7, 2011.

FARIAS, M. R. Avaliação da qualidade de matériasprimas vegetais. In: SIMÕES, C. M. O.; SCHENKEL, E. P.; GOSMANN, G.; MELlO, J. C. P.; MENTZ, L. A.; PETROVICK, P. R. Farmacognosia: da planta ao Medicamento. 5. ed. Florianópolis, Porto Alegre: UFSC; UFRS, cap.12, p. 263-88,2004.

FERNANDES, E. S.; PASSOS, G. F.; MEDEIROS, R.; CUNHA, F. M.; FERREIRA, J.; CAMPOS, M. M.; PIANOWSKI, L. F.; CALIXTO, J. B. Os efeitos antiinflamatórios dos compostos de alfa-humuleno e (-) trans-cariofileno isolados a partir do óleo essencial de Cordia verbenácea. European Journal of Pharmacology, Amsterdam, v. 569, n. 3, p. 228-236, 2007.

FERRONATTO, R.; MARCHESAN, E. D.; PEZENTI, E.; BEDNARSKI, F.; ONOFRE, S. B. Atividade antimicrobiana de óleos essenciais produzidos por Baccharis dracunculifoli D.C. e Baccharis uncinella D.C. (Asteraceae), Revista Brasileira de farmacognosia., João Pessoa, v. 17, n. 2, p. 224, 2007.

FREITAS, M. R. V.; SILVA, J. M.; SILVA, D. G. R.; NASCIMENTO, K. T. O.; SIMOES, S. S.; COSTA, J. A.; SILVA, C. D.; SA, R. A.; NAPOLEÃO, T. H.; NAVARRO, D. M. A. F. Avaliação da atividade antifúngica do óleo essencial de Baccharis dracunculifolia frente a fungos fitopatogênicos do gênero Fusarium. Recife: [s.n.], 2016. Disponível em: <http://www.abq.org.br/cbq/2012/ trabalhos/7/1660-13827.html>. Acesso em: 10 abr. 2016.

GUENTHER, E. The essential oils. $6^{\text {th }}$ ed. Huntington: R. E. Krieger, 1972. 63 p.

GUTIÉRREZ, R. M. P.; MITCHELL, S.; SOLIS, R. V. Psidium guajava: a review of its 264 traditional uses, phytochemistry and pharmacology. Journal of Ethnopharmacology, Clare, v. 117, n. 265 p. 1-27, 2008.

INTERNATIONAL ORGANIZATION FOR STANDARDIZATION - ISO. Aromatic natural raw materials - Vocabulary: ISO 9235. Genebra: NSAI Standars 54, 1997. 8 p.

ISENBERG, C.; NOZAKI, M. de H. Influence of temperature and drying position of medicinal plants in a dryer based on solar energy. Revista Acadêmica: Ciências Agrárias e Ambientais, São José dos Pinhais, v. 9, n. 1, p. 57-64, 2011.

KANERIA, M.; CHANDA, S. Phytochemical and pharmacognostic evaluation of leaves of Psidium guajava L. (Myrtaceae). Pharmacognosy Journal, Bangalore, v. 3, n. 23, p. 41-45, 2011. 
KHANGHOLI, S. H.; REZAEINODEHI, A. Effect of drying temperature on essential oil content and composition of sweet wormwood (Artemisia annua L.) growing wild in Iran. Pakistan Journal of Biological Science, Pakistan, v. 11, n. 6, p. 934-937, 2008.

KHATER, H. F.; HANAFY, A.; MAGEED, A. D. A.; RAMADAN, M.; MADAWY, H. F. E. Control of the myiasis-producing fly, Lucilia sericata, with Egyptian essential oils. International Journal of Dermatology, Cambridge, v. 50, n. 2, p. 187-194, 2011.

LIMA, R. K.; CARDOSO, M. G.; SANTOS, C. D.; MORAES, J. C.; NERI, D. K. P.; NASCIMENTO, E. A. Essential oil chemical composition from leaves of guava (Psidium 269 guajava L.) and its effects on the fall armyworm Spodoptera frugiperda (J. E. Smith, 1797). 270 (Lepidoptera: Noctuidae) behavior. Ciência e Agrotecnologia., Lavras, v. 33, p. 1777-1781, 2009. Edição Especial.

MACHADO, M. P.; BERGO, C. L.; DESCHAMPS, C.; BIZZO, H. R.; BIASI, L. A. Effect of the natural and artificial drying of leaf biomass Piper hispidinervum on the chemical composition of the essential oil. Semina: Ciências Agrárias, Londrina, v. 34, n. 1, p. 265-270, 2013.

MARTINS, P. M.; MELO, E. C.; ALMEIDA, L. C. B.; SANTOS, R. H. S.; MACHADO, M. C. Influência da temperatura e velocidade do ar de secagem no teor e na composição química do óleo essencial de capimlimão (Cymbopogon citratus Stapf). Acta Horticulturae, Leuven, v.1, n. 569, p. 1-10, 2002.

MEVY, J. P.; BESSIERE, J. M.; DHERBOMEZ, M.; MILLOGO, J.; VIANO, J. Chemical composition and some biological activities of the volatile oils of a chemotype of Lippia chevalieri Moldenke. Food Chemistry, London, v. 101, n. 2, p. 682-685, 2007.

OMIDBAIGI, R.; SEFIDKON, F.; KAZEMI, F. Influência do método de secagem sobre o teor de óleo essencial e composição da camomila romana, Flavour and Fragrance Journal, Chichester, v. 19, p. 196-198, 2004. Edição Especial.

PINO, J. A.; AGUERO, J.; MARBOT, R.; FUENTES, V. Leaf oil of Psidium guajava L. from Cuba. Journal Essential Oil Research, Carlo Stream, v. 31, n. 1, p. 6162, jan./feb. 2001.

RADÜNZ, L. L.; MELO, E. C.; ROCHA, P. P.; BERBERT, P. A.; GRACIA, L. M. N. Study of essential oil from guaco leaves submitted to different drying air temperature. Engenharia na Agricultura, Viçosa, MG, v. 18, n. 3, p. 241-247, 2010.
ROSADO, L. D. S.; PINTO, J. E. B. P.; BOTREL, P. P.; BERTOLUCCI, S. K. V.; NICULAU, E. S.; ALVES, P. $B$. Influence of leaf processing and type of drying on the content and chemical composition of the essential oil of basil cv. Maria Bonita. Ciência e Agrotecnologia, Lavras, v. 35, n. 2, p. 291-296, 2011.

ROSAS, J. F.; SILVA, A. C. M.; ZOGHBI, M. G. B.; ANDRADE, E. H. A. Comparação dos voláteis das folhas de Ocimum micranthum Willd obtidos por hidrodestilação e destilação-extração simultânea. Revista Brasileira de Plantas Medicinais, Botucatu, v. 7, n. 1, p. 26-29, 2004.

SANTOS, I.; SANTOS, T.; SILVA, F.; GAGLIARDI, P.; OLIVEIRA JÚNIOR, L.; BLANK, A. Óleo essencial de Schinus terebinthifolius Raddi como controle alternativo de Colletothrichum gloeosporioides e Lasiodiplodia theobromae, fungos fitopatogênicos de pós-colheita. Revista GEINTEC, São Cristovão, v. 4, n. 4, p. 14091417, 2014.

SELLAMI, I. H.; WANNES, W. A.; BETTAIEB, I.; BERRIMA, S.; CHAHED, T.; MARZOUK, B.; LIMAM, F. Qualitative and quantitative changes in the essential oil of Laurus nobilis L. leaves as affected by different drying methods. Food Chemistry, London, v. 126, n. 2, p. 691697, 2011.

SHAH, A. J.; BEGUN, S.; HASSAN, S. I.; ALI, S. N.; SIDDIQUI, B. S.; GILANI, A. H. Pharmacological basis for the medicinal use of Psidium guajava leave in hyperactive gut disorders. Bangladesh Journal of Pharmacology, Dhaka, v. 6, n. 2, p. 100-105, 2011.

SHAHHOSEINI, R.; GHORBANI, H.; KAMIRI, S. R.; ESTAJI, A.; MOGHADDAM, M. Qualitative and quantitative changes in the essential oil of lemon verbena (Lippia citriodora) as Affected by drying condition. Drying Technology: An International Journal, Philadelphia, v. 31, n. 9, p. 1020-1028, 2013.

SIMÕES, C. M.; SPITZER, V. Óleos voláteis. In: SIMÕES, C. M. O.; SCHENKEL, E. P.; GOSMANN, G.; MELLO, J. C. P.; MENTZ, L. A.; PETROVICK, P. R. Farmacognosia: da planta ao medicamento. 6. ed. Porto Alegre: UFSC, 2007.

SOMAN, S.; RAJAMANICKAM, C.; RAUF, A. A.; INDIRA, M. Beneficial effects of Psidium guajava leaf extract on diabetic myocardium. Experimental and Toxicologic Pathology, Jena v. 65, n. 1-2, p. 91-95, 2013.

SOUZA, S. A. M.; MEIRA, M. R.; FIGUEIREDO, L. S.; MARTINS, E. R. Óleos essenciais: aspectos econômicos e sustentáveis. Enciclopédia Biosfera. Centro Científico Conhecer, Goiânia, v. 6, n. 10, p. 1-2, 2010. 
TAVARES, A. A.; SAMPAIO, M. C. C.; SAMPAIO, F. C.; MELO, A. F. M.; SENA, K. X. F. R.; CHIAPPETA, A. A; HIGINO, J. S. Atividade antimicrobiana in vitro de extratos hidroalcoólicos de Psidium guajava L. sobre bactérias gram-negativas. Acta Farmacéutica Bonaerense, Buenos Aires, v. 21, n. 4, p. 255-258, 2002.
TELES, S. Avaliação do teor e da composição química de Lippia alba (Mill) N.E.BR. $r$ Mentha piperita L. cultivadas em Cruz das Almas, Santo Antonio de Jesus e Amargosa, submetidas ás diferentes épocas de colheita e processos de secagem. 2010. (Mestrado em Ciências Agrárias) - Curso de Pós-Graduação em Ciências Agrárias. Centro de Ciências Agrárias. Ambientais e Biológicas. Universidade Federal do Recôncavo da Bahia, Bahia. 